\title{
Tolerance of Atlantic cod (Gadus morhua L.) larvae to acute ammonia exposure
}

\author{
Terje van der Meeren $^{1}$ (DD $\cdot$ Anders Mangor-Jensen ${ }^{1}$
}

Received: 6 September 2019 / Accepted: 22 April 2020 / Published online: 6 May 2020

(C) The Author(s) 2020

\begin{abstract}
Tolerance for acute ammonia exposure, defined to exist between NOEC (no observed effect concentration) and LOEC (lowest observed effect concentration), was validated in seven exposure experiments with Atlantic cod larvae from 15 to 63 days post-hatch, corresponding to larval sizes of 0.2 to $4.9 \mathrm{mg}$ dry weight, respectively. LOEC was found in the range of $0.019-0.082 \mathrm{mg} \mathrm{L}^{-1} \mathrm{NH}_{3}-\mathrm{N}$, with corresponding NOECs of 0.013$0.045 \mathrm{mg} \mathrm{L}^{-1} \mathrm{NH}_{3}-\mathrm{N}$. Cod larvae of 1.0 and $1.7 \mathrm{mg}$ dry weight (33 and 42 days after hatching) were found to be most sensitive and had the highest mortality to acute ammonia exposure, indicating ontogenetic changes in ammonia tolerance. The results suggest that specific care needs to be taken in designing and monitoring rearing systems, particularly recirculation systems, for toxic ammonia levels regarding larval rearing of Atlantic cod.
\end{abstract}

Keywords Ammonia tolerance $\cdot$ Atlantic cod larvae $\cdot$ Acute toxicity Intensive larviculture Larval rearing

\section{Introduction}

Development of commercial fish farming requires controlled and predictable production of juveniles. For many marine fish species, larval and juvenile production methods have developed into high-density intensive systems, with a recent increasing interest for recirculation aquaculture systems (RAS). This intensification elevates the risk of larval and juvenile fish to be exposed to deteriorated water quality from accumulation of harmful metabolites, of which ammonia is of prime concern.

Ammonia is a special case in toxicology since it is both an environmental toxicant and a waste product from living organisms. Fish, particularly their larvae, produces ammonia mainly through amino acid and nucleotide catabolism (Wright and Fyhn 2001). In open flow-through

Terje van der Meeren

Terje.van.der.Meeren@hi.no

1 Institute of Marine Research, Austevoll Research Station, Sauganeset 16, NO-5392 Storebø, Norway 
aquaculture systems where the water is constantly renewed from an uncontaminated source, toxic ammonia levels are avoided by sufficient flow rate. However, in RAS ammonia may build up unless proper precautions are taken. In such rearing systems, the removal of ammonia is primarily achieved by the bacteria Nitrosomonas sp. and Nitrobacter $\mathrm{sp}$. in the presence of water saturated with oxygen to form nitrite and nitrate, respectively. These ions are far less toxic than ammonia (Brownell 1980; Wang et al. 2015), although build-ups of nitrate also may be harmful (Pierce et al. 1993). With a well-working biofilter, water renewal may therefore be reduced to only a small fraction of the total water turnover. RAS normally hold a $\mathrm{pH}$ lower than clean seawater due to respiration from the concentrated biomass in RAS and production of $\mathrm{H}^{+}$in the first step of the nitrification process in the biofilters (Shanahan and Semmens 2015). Lower $\mathrm{pH}$ will cause a shift of ammonia towards the lesser toxic ionized form. However, small increases in $\mathrm{pH}$, or a dysfunctional biofilter, may cause the ammonia concentration to increase rapidly into acute toxic levels.

The use of RAS in production of marine fish fry has been suggested, including for start feeding of the cold-water species Atlantic cod (Gadus morhua L.) (Attramadal et al. 2012). Compared with freshwater, establishment of full-grown functional biofilms in seawater RAS takes long time (Nijhof and Bovendeur 1990), with low temperature also severely reducing biofilter efficiency (Noble and Summerfeldt 1996). Thus, cold-water marine recirculation systems may be particularly susceptible to ammonia accumulation. Any inadequacies in the biofilter may increase ammonia with the potential to reach acute toxic levels and subsequent decrease in larval fish welfare and survival.

In aqueous solutions, total ammonia nitrogen (TAN) is present as unionized ammonia $\left(\mathrm{NH}_{3}\right)$ and ionized ammonium $\left(\mathrm{NH}_{4}{ }^{+}\right)$, and the equilibrium is dependent on $\mathrm{pH}$, temperature, and salinity (Whitfield 1974; Soderberg and Meade 1991; Eddy 2005). The $\mathrm{NH}_{3}$ fraction increases with elevated $\mathrm{pH}$ and temperature and declines with increasing ionic strength. At physiological $\mathrm{pH}$, ammonia is mainly present as $\mathrm{NH}_{4}^{+}$, but small changes in $\mathrm{pH}$ result in dramatic increases of the $\mathrm{NH}_{3}$ fraction, especially around the $\mathrm{pK} \sim 9.5 . \mathrm{NH}_{3}$ moves freely across most biological membranes, whereas $\mathrm{NH}_{4}{ }^{+}$is less permeable (Cameron and Heisler 1983; Eddy 2005). Both forms of TAN are toxic, but toxicity is particularly related to $\mathrm{NH}_{3}$ concentration and becomes acute when elevated to the range of $0.09-3.35 \mathrm{mg} \mathrm{L}^{-1} \mathrm{NH}_{3}-\mathrm{N}$ for marine fish (Handy and Poxton 1993). Toxicity of chronic exposure occurs at lower $\mathrm{NH}_{3}$ concentrations, in the range of 5-10\% of acute tolerance (Eddy 2005). Dissolved oxygen may also influence on ammonia toxicity, as low oxygen levels increased toxicity of $\mathrm{NH}_{3}$ (Alabaster et al.1979).

Most nitrogenous waste in fish is excreted as $\mathrm{NH}_{3}$ to the ambient water by diffusion across the cell membranes in the gills. Ammonia excretion in marine fish may also involve membrane transporters where the excess $\mathrm{H}^{+}$ions from cellular $\mathrm{NH}_{4}{ }^{+}$are exchanged with $\mathrm{Na}^{+}$ions, facilitating $\mathrm{NH}_{3}$ diffusion by an acid-trapping mechanism in the tissue-water boundary layer along with a $\mathrm{pH}$ drop from $\mathrm{CO}_{2}$ excretion. Recent studies also suggest direct $\mathrm{NH}_{4}{ }^{+}$secretion through membrane ion exchangers and species-specific differences among marine fishes (reviewed by Terjesen 2008; Weihrauch et al. 2009; Wright and Wood 2012).

Elevated ammonia levels in the environment either impair ammonia excretion or cause a net uptake of ammonia from the environment. This may cause histological damage to the gills of fishes, which in turn may compromise gas exchange, ion regulation, and acid-base regulation (Wilkie 2002). Elevated body concentrations of ammonia may further act on nerve conduction and membrane transport, $\mathrm{Na}^{+}-\mathrm{K}^{+}$-ATPase activity, neurotransmitter metabolism, cell metabolism, reactive oxygen species (ROS), $\mathrm{Ca}^{2+}$ homeostasis, and intracellular $\mathrm{pH}$ (Felipo and 
Butterworth 2002; Alam and Frankel 2006; Cheng et al. 2015), leading to neurotoxicity, kidney hyperaemia, dilatation of liver structures, DNA damage, cell apoptosis, and interference with oxidative metabolism and oxygen delivery (Wilkie 2002, Rodrigues et al. 2014; Cheng et al. 2015). Endogenous waste products, such as carbon dioxide, may interact with ammonia during exposure. High blood $\mathrm{CO}_{2}$ levels (hypercapnia) lead to acid-base disturbances in teleosts and may increase ammonia toxicity (Ip et al. 2001). Symptoms of ammonia poisoning in fish include reduced feed intake, growth and swimming ability, as well as hyperventilation, coma, convulsions, and death (Ip et al. 2001). Further, early life stages in fishes may lack specialized structures for effective excretion of nitrogenous waste (Morrison 1993 ) and may therefore be more vulnerable to exogenous ammonia. Knowledge of both acute and chronic ammonia tolerance in cultivated marine fish species, particularly in larval stages, are therefore of prime interest.

Regarding cold-water species, decreased food intake and subsequent reduction of growth has been reported in juveniles of Atlantic cod (Gadus morhua L.) chronically exposed to $\mathrm{NH}_{3}-\mathrm{N}$ concentrations above $0.06 \mathrm{mg} \mathrm{L}{ }^{-1}$ (Foss et al. 2004; Remen et al. 2008). However, no tolerance levels for acute or chronic exposure have been reported for larval stages of this species. Consequently, the present study investigates tolerance levels throughout the developmental stages for larval Atlantic cod, with reference to acute exposure of ammonia.

\section{Materials and methods}

\section{Larval rearing}

Cod larvae were obtained from autumn-spawned eggs collected from photoperiod-controlled broodstock fish (van der Meeren and Ivannikov 2006) kept at the commercial hatchery (Havlandet Marin Yngel AS, Florø, Norway). Newly spawned eggs were shipped to the Institute of Marine Research, Austevoll Research Station (IMR-Austevoll). Egg incubation and hatching methods are described in van der Meeren et al. (2007). About 60,000 3-day-old cod larvae were reared in a flow-through system, in one $1.5-\mathrm{m}^{3}$ black fibreglass tank with a collar lid (peripheral cover) to shade the tank wall. Algal paste (Nannochloropsis, Reed Mariculture Inc., Campbell, CA, USA) was supplied continuously from a header tank by Iwaki EH/S membrane pumps (Iwaki Co. Ltd., Tokyo, Japan) to achieve green water for enhancement of larval feeding (van der Meeren et al. 2007). Algal density was monitored by measuring turbidity that was kept between 1 and 2 NTU (nephelometric turbidity unit) as measured by a Hach 2100P turbidimeter (Hach Company, Loveland, CO, USA). Light was provided through standard daylight roof-mounted luminaires with fluorescent light tubes. Water naturally low in ammonia $\left(<0.0001 \mathrm{mg} \mathrm{L}^{-1} \mathrm{NH}_{3}-\mathrm{N}\right.$, as calculated from TAN in 7 triplicate samples throughout the rearing period) was pumped from $160 \mathrm{~m}$ depth in the fjord outside the rearing facility. This water was sand-filtered and temperature-regulated before being aerated and supplied to the rearing tank. Water temperature in the rearing tank was raised by a smooth transition of $1{ }^{\circ} \mathrm{C}$ increase per day from the hatching temperature of 6 to slightly above $12^{\circ} \mathrm{C}$ at day 6 post-hatch (dph). Hydrographical data (means $\pm \mathrm{SD}$ ) over the rearing period are shown in Table 2. Surface skimming and outlet sieve system used are detailed in van der Meeren et al. (2007). All hydrographical data were collected daily by an YS1 6600 probe (YSI Environmental, Yellow Springs, OH, USA). 
Larval rearing and feeding protocols are described in van der Meeren et al. (2007), with adjustments in water flow rate and amounts of live feed relative to the larger tank size in the present experiment. Rotifers (Brachionus plicatilis, Cayman strain) grown on Rotimac (BioMarine Aquafauna Inc., Hawthorne, CA, USA) were used as live feed during the first 30 days, followed by 10 days of Artemia enriched with DHA Selco (INVE Aquaculture, Dendermonde, Belgium). Live feed was added 2-3 times a day, depending on clearance of larval prey in the rearing tank. Feeding was assumed to be at satiation, as some prey always remained at the next feed addition. At $40 \mathrm{dph}$, the cod larvae were weaned on a mix of GEMMA Micro (Skretting-Nutreco, Stavanger, Norway) and AgloNorse (Ewos AS, Bergen, Norway). The formulated feed was added continuously by a belt feeder.

\section{Ammonia exposure experiments}

The study was carried out within the Norwegian animal welfare act guidelines, in accordance with the Animal Welfare Act of 20 December 1974 (revised 19 June 2009), at the IMRAustevoll facility which has a general permission to conduct experiments involving all developmental stages of fish (code 093) provided by the Norwegian Animal Research Authority (FDU, www.fdu.no). The experiment was in accordance with a permission given by FDU (FOTS ID 13907). All means to minimize larval mortality were carried out by carefully selecting ammonia exposure concentrations.

Ranges of the ammonia concentrations were initially selected based on previous experience with larval mortality associated with elevated ammonia levels during start feeding of cod and Atlantic halibut (Hippoglossus hippoglossus L.) at IMR-Austevoll but also from previously published data on other larval fish species (Brownell 1980; Guillén et al. 1993, 1994; Parra and Yúfera 1999). The highest dosage used in any of the experiments was evaluated consecutively from the results of the previous exposure trials in the present study. Adjustments of the concentrations were necessary as it turned out that tolerance levels changed with larval development. In this way, the four ammonia concentrations used in an exposure experiment were not the same for cod larvae at different ages (Table 1).

In management of animal welfare, mortality and sub-lethal effects are to be minimized. Therefore, an approach different than determining lethal levels of ammonia (e.g. $\mathrm{LC}_{50}$ ) was chosen. Since an effect may occur at lower concentrations than would correspond to $\mathrm{LC}_{50}$,

Table 1 Ammonia concentrations (TAN, $\mathrm{mg} \mathrm{L}^{-1}$ ) used in the exposure experiments (exp.1 to 7), given as mean $\pm \mathrm{SD}$ of three replicate samples

\begin{tabular}{llllll}
\hline & Control & Dose 1 & Dose 2 & Dose 3 & Dose 4 \\
\hline Larval rearing tank & $0.003 \pm 0.003$ & & & & \\
Day 15 (exp.1) & $0.008 *$ & $0.12 \pm 0.007$ & $0.21 \pm 0.004$ & $0.41 \pm 0.006$ & $0.87 \pm 0.009$ \\
Day 20 (exp.2) & n.d. & $0.33 \pm 0.002$ & $0.69 \pm 0.009$ & $1.13 \pm 0.012$ & $2.89 \pm 0.237$ \\
Day 24 (exp.3) & $0.002 \pm 0.003$ & $0.68 \pm 0.016$ & $0.99 \pm 0.106$ & $2.70 \pm 0.053$ & $4.93 \pm 0.046$ \\
Day 33 (exp.4) & $0.004 \pm 0.003$ & $0.70 \pm 0.016$ & $1.06 \pm 0.114$ & $2.89 \pm 0.055$ & $5.18 \pm 0.047$ \\
Day 42 (exp.5) & $0.005 \pm 0.004$ & $0.20 \pm 0.003$ & $0.41 \pm 0.006$ & $0.72 \pm 0.017$ & $1.54 \pm 0.027$ \\
Day 58 (exp.6) & n.d. & $0.18 \pm 0.001$ & $0.43 \pm 0.003$ & $0.61 \pm 0.002$ & $1.58 \pm 0.057$ \\
Day 63 (exp.7) & $0.005 \pm 0.001$ & $0.67 \pm 0.005$ & $1.34 \pm 0.024$ & $2.39 \pm 0.003$ & $4.52 \pm 0.026$ \\
\hline
\end{tabular}

*Only one replicate

Age denotes days post-hatch, and n.d. means not detectable. Value for larval rearing tank represents TAN in inlet water 
tolerance was defined to exist between NOEC (no observed effect concentration) and LOEC (lowest observed effect concentration). NOEC was the highest concentration that did not elevate larval mortality significantly of the dose-response curve, and LOEC was correspondingly the lowest concentration that spurred a significant increase in larval mortality. The use of NOEC and LOEC has been criticized (Crane and Newman 2000) but is frequently used by managers and agencies to establish safe limits of factors or agents affecting animal welfare.

A flow-through exposure system was chosen to prevent bias in ammonia concentration from, e.g. excretion or bacterial activity during exposure. This biotest rig consisted of five sets of triplicate green circular 35-1 exposure tanks of PE plastic, five 40-1 header tanks (one for each triplicate) with trickling aerator above the centre of the tank and air bubbling for mixing, and an ammonia stock solution tank equipped with a continuous dosage system of four Iwaki $\mathrm{EH} / \mathrm{S}$ membrane pumps (one for each header tank used to enrich the supplied water with ammonia) (Fig. 1). In this way, larvae were exposed to four different ammonia concentrations in triplicates, along with a triplicate control in which no ammonia was added. No feed or green water that could affect ammonia concentration were used during exposure. To reduce any build-up of biofilm, the water was drained, and the tanks were cleaned between the experiments.

Ammonia concentrate was made from analytic grade $\mathrm{NH}_{4} \mathrm{Cl}$ (Merck, Darmstadt, Germany) dissolved in a 5-1 freshwater container before adding this to the 250-1 ammonia concentrate tank (Fig. 1). Continuous air bubbling was used to ensure proper mixing. To prevent decline in dosage pump rate from reduced water level in the ammonia concentrate tank, another pump was used to fill an internal level tank with overflow inside the ammonia concentrate tank. In

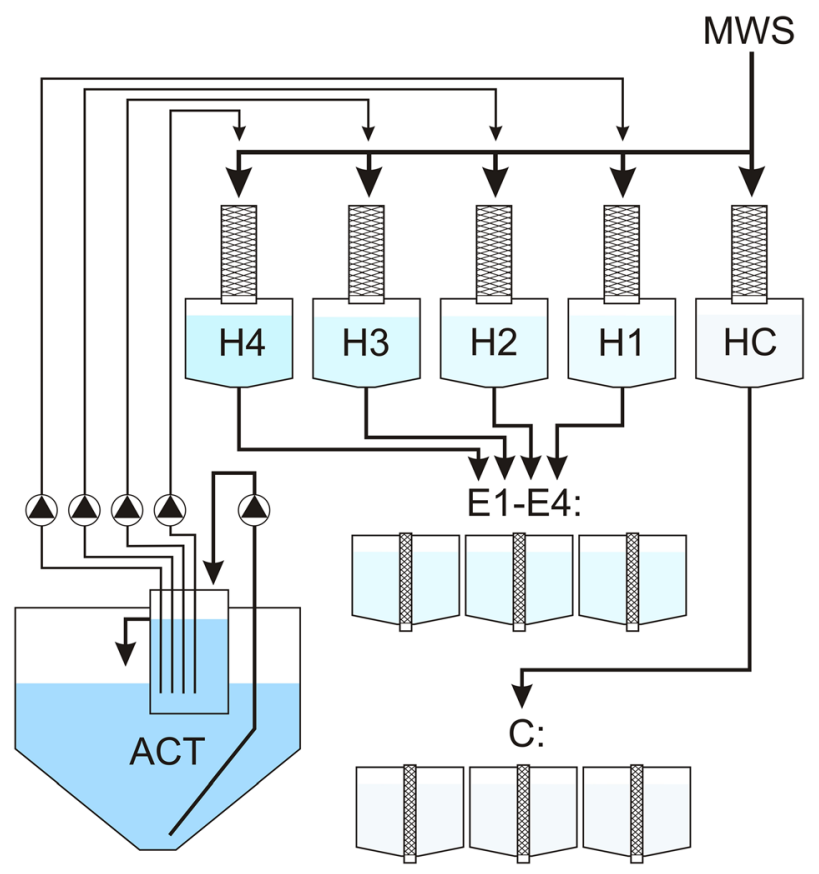

Fig. 1 Schematic drawing of the ammonia exposure rig system. MWS, main water supply; H1-H4, header tanks for mixing of four different ammonia concentrations; HC, header tank for control; ACT, ammonia concentrate tank with dosage pumps and an internal level tank with overflow for stable supply of concentrate; E1-E4, four triplet tank series for larval ammonia exposure; C, triplet tank series for unexposed control 
this way, the dosage pumps would face constant water level on the suction side, preventing a reduction in ammonia concentrate doses, measured to be $17 \%$ if the dosage pumps had to suck directly from the ammonia concentrate tank. The calculated ammonia concentration from the dosage system delivered to the exposure tanks was found to deviate $8.8 \% \pm 9.2($ mean $\pm \mathrm{SD}$ ) from measured ammonia concentrations over the whole range of concentrations used. Thus, the calculated concentrations were regarded as good proxies for the actual exposure concentrations, and the setup of the biotest rig (Fig. 1) was evaluated as a robust system to maintain a steady deliver of ammonia close to the desired concentrations. Exposure concentrations were sampled and analysed mid-way in the exposure period, and only measured concentrations were used in determining ammonia tolerance. The variability of ammonia concentration was checked by taking three samples in triplicates through an exposure period. The coefficient of variation of these three samples was $2.2 \%$, indicating high stability in delivered ammonia concentration to the exposure tanks.

Water samples were analysed for TAN content, using the salicylate-hypochlorite method (Bower and Holm-Hansen 1980). Each sample was prepared in triplicate before analysis. Variation coefficients between triplicates were at maximum $10 \%$ but mostly below $2 \%$. Absorbance of the ammonium reaction compound indophenol blue was detected by a Shimadzu UV-160 spectrophotometer (Shimadzu Corporation, Kyoto, Japan), and TAN content was determined from standard curves. Since the relationship between ammonium concentration and absorbance was not linear over the ranges of TAN concentrations used, polynomials were fitted to the standard curve data. At high TAN concentrations, samples were diluted to $1 / 10$ before analysis. Calculation of unionized ammonia $\left(\mathrm{NH}_{3}\right)$ fraction was done from a minor correction of Fivelstad (1988) as compiled from Whitfield (1974):

$$
\% \mathrm{NH}_{3}=100 /(1+\operatorname{antilog}((9.245+0.116 * I)+(0.0324 *(24.85-t))-p H))
$$

In this equation, $t$ is temperature $\left({ }^{\circ} \mathrm{C}\right)$, and $I$ is molar ionic strength of standard sea water, given by the formula:

$$
I=19.9273 * S /(1000-1.005109 * S)
$$

where $S$ is salinity (\%o) (Whitfield 1974). Variation in TAN among the triplicate exposure tanks was checked in one of the experiments and found to be low ( $2.5 \%$ coefficient of variation).

Cod larvae were gently transferred from the rearing tank to the biotest rig at 15, 20, 24, 33, 42,58 , and $63 \mathrm{dph}$ where they were exposed to ammonia for $48 \mathrm{~h}$. Each exposure tank was initially stocked with 50 larvae (except for the 2nd trial where 40 larvae were used), and mortality was monitored over two observation periods. Larval mortality was determined by removing dead individuals from the tank bottoms at 24 and $48 \mathrm{~h}$ after onset of the experiment, giving two observation periods, 0-24 and 24-48 h after initiation of an exposure trial. Mortality from the latter observation period was calculated from the remaining larvae at $24 \mathrm{~h}$. At transfer to the exposure tanks, dry weights (DW) were determined of another 30 individuals from the rearing tank. These larvae were anesthetized and killed with an excess dose of tricaine methanesulfonate (500 mg L $\left.\mathrm{mS}^{-1} \mathrm{MS2}\right)$, rinsed in distilled water, and dried for $72 \mathrm{~h}$ in a Heto FD8 freeze drier (Heto-Holten AS, Allerød, Denmark). DW was determined by a Mettler Toledo UMX2 balance (Mettler Toledo Inc., Columbus, OH, USA). Hydrographical data was collected from each of the exposure concentrations of the experiments. 


\section{Statistics}

Within each exposure trial, mortality data was analysed with one-way ANOVA followed by Dunnett's post hoc test for determining if ammonia treatments were significantly higher than the control. The mortality data, expressed as percentages, were arcsine transformed (Sokal and Rohlf 1995) before analysis. In the ANOVA, the Hartley's, Cochran's C, and Bartlett's tests for homogeneity of variances were applied, and as 5 of the 21 exposure trials came out with heteroscedasticity, the Dunnett's post hoc test was replaced by the Games and Howell method (Sokal and Rohlf 1995) for comparison of the ammonia treatments with the control in these trials. Except for the Games and Howell method, all statistical analyses were carried out by STATISTICA 12 (StatSoft Inc., Tulsa, OK, USA). Further, difference in mortalities between the exposure trials, e.g. between observation periods or larval age (size), were analysed by covariance (ANCOVA) with the ammonia concentration as the covariate, followed by Tukey's HSD post hoc test. A significance level of 0.05 was used in all statistical tests.

\section{Results}

Larval rearing and the exposure experiments had low variation in hydrographical conditions (Table 2). In most of the exposures, mortality increased with increasing ammonia concentration in both observation periods (Fig. 2). Except for in 33 and 42-day-old larvae and at the highest ammonia concentrations, mortality was close to or below $20 \%$ after $24-\mathrm{h}$ exposure or $10 \%$ during the second observation period between 24 and $48 \mathrm{~h}$. However, no significant difference was found in mortality between the two observation periods (ANCOVA, $p=0.902$ ).

Larval mortality during both observation periods was significantly higher during the exposure trials carried out at 33 and $42 \mathrm{dph}$ (larval sizes of 1.0 and $1.7 \mathrm{mg} \mathrm{DW}$, respectively; Fig. 2) than in previous or later trials (ANCOVA, $p<0.001$; Tukey's HSD post hoc test, $p<0.001)$.

Within each exposure trial, at specific larval ages or sizes, the highest ammonia concentration that did not significantly elevate larval mortality (i.e. NOEC) was in the

Table 2 Hydrographical data and larval size (mean $\pm \mathrm{SD}$ ) for the larval rearing tank and the exposure experiments (exp.1 to 7)

Larval size (mg DW) Temperature $\left({ }^{\circ} \mathrm{C}\right) \begin{aligned} & \text { Salinity } \\ & (\mathrm{psu})\end{aligned} \quad$ Oxygen sat. $(\%) \mathrm{pH}$

\begin{tabular}{llllll}
\hline Larval rearing tank & - & $12.18 \pm 0.11$ & $35.06 \pm 0.07$ & $97.1 \pm 3.7$ & $7.93 \pm 0.09$ \\
Day 15 (exp.1) & $0.211 \pm 0.047$ & $12.27 \pm 0.07$ & $34.96 \pm 0.16$ & $98.7 \pm 0.4$ & $7.89 \pm 0.03$ \\
Day 20 (exp.2) & $0.414 \pm 0.207$ & $12.17 \pm 0.09$ & $34.96 \pm 0.12$ & $100.0 \pm 0.7$ & $7.95 \pm 0.01$ \\
Day 24 (exp.3) & $0.569 \pm 0.191$ & $12.33 \pm 0.19$ & $34.98 \pm 0.10$ & $99.8 \pm 0.6$ & $7.96 \pm 0.02$ \\
Day 33 (exp.4) & $1.015 \pm 0.183$ & $12.30 \pm 0.19$ & $35.02 \pm 0.11$ & $102.1 \pm 0.6$ & $8.00 \pm 0.02$ \\
Day 42 (exp.5) & $1.678 \pm 0.431$ & $12.13 \pm 0.05$ & $34.85 \pm 0.12$ & $99.7 \pm 0.4$ & $7.99 \pm 0.01$ \\
Day 58 (exp.6) & $4.341 \pm 1.367$ & $12.19 \pm 0.10$ & $34.93 \pm 0.12$ & $95.8 \pm 2.6$ & $8.03 \pm 0.01$ \\
Day 63 (Exp.7) & $4.938 \pm 1.944$ & $11.91 \pm 0.03$ & $34.89 \pm 0.11$ & $101.1 \pm 0.2$ & $8.03 \pm 0.01$ \\
\hline
\end{tabular}

*Hydrography is only shown for the period with stable rearing temperature (day 6 to day 63), after the increase of temperature initiated at hatching

Age denotes days post-hatch 


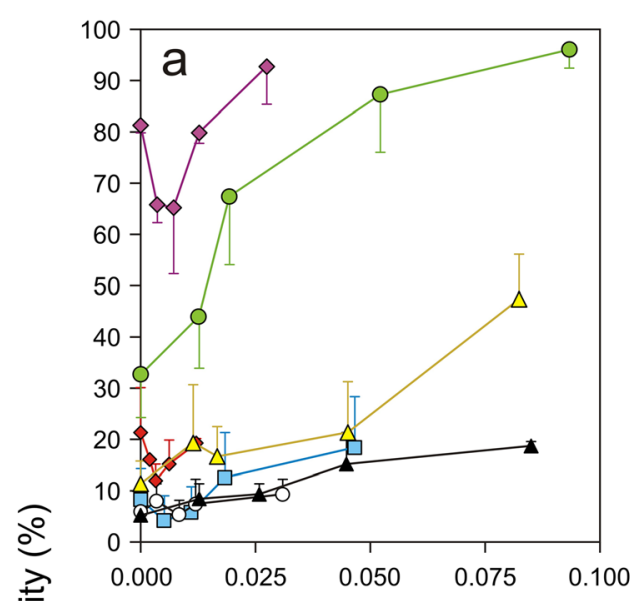

Larval weight/age:

$\diamond 0.211 \mathrm{mg} / 15 \mathrm{dph}$

$\rightarrow-0.414 \mathrm{mg} / 20 \mathrm{dph}$

$\triangle 0.569 \mathrm{mg} / 24 \mathrm{dph}$

- $-1.015 \mathrm{mg} / 33 \mathrm{dph}$

$\checkmark 1.678 \mathrm{mg} / 42 \mathrm{dph}$

$-0-4.341 \mathrm{mg} / 58 \mathrm{dph}$

$\_4.938 \mathrm{mg} / 63 \mathrm{dph}$

\section{$\frac{2}{2}$}
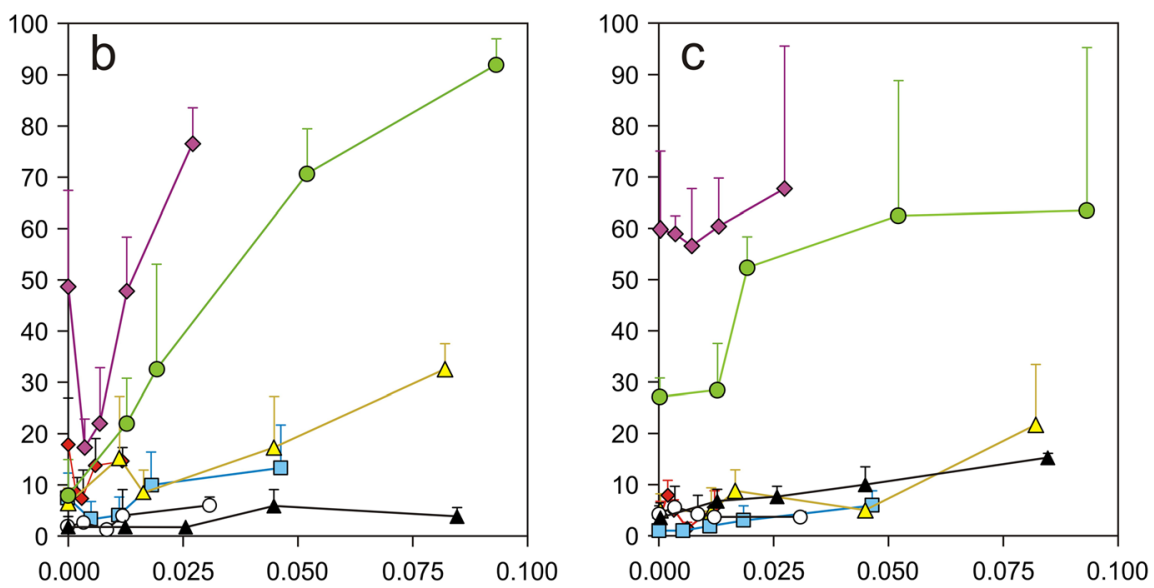

\section{Ammonia $\mathrm{NH}_{3}-\mathrm{N}\left(\mathrm{mg} \mathrm{L}^{-1}\right)$}

Fig. 2 Average mortality of larval cod at different sizes and ages, plotted on the corresponding ammonia exposure concentrations (symbols) for $48 \mathrm{~h} \mathrm{(a),} \mathrm{the} \mathrm{first} 24 \mathrm{~h} \mathrm{(b)}$, and the last $24 \mathrm{~h} \mathrm{(c),} \mathrm{as} \mathrm{calculated} \mathrm{from} \mathrm{the}$ beginning of each time interval. The curves represent change in larval mortality with increasing ammonia concentration in the exposure experiments. Error bars are standard deviations of larval mortality for three replicate exposure tanks in the biotest rig

range of 0.012 and $0.046 \mathrm{mg} \mathrm{L}^{-1} \mathrm{NH}_{3}-\mathrm{N}$ (Table 3). As no effect was observed at the highest ammonia concentrations used in the exposure experiments carried out at 15,20 , and $58 \mathrm{dph}$, upper limits of tolerance could therefore not be established for cod larvae below $0.5 \mathrm{mg}$ or at $4.3 \mathrm{mg} \mathrm{DW}$.

Actual tolerance at a specific age and larval size are found between the highest ammonia concentration that did not give an effect on mortality and the concentration that inflicted a significant increase in mortality (i.e. LOEC). This could be established for the exposure experiments at 24 to 42 and $63 \mathrm{dph}$, equivalent to larval sizes 0.6 to $1.7 \mathrm{mg} \mathrm{DW}$, and at $4.9 \mathrm{mg} \mathrm{DW}$, respectively. For these larval ages and sizes, LOEC varied between 0.019 and $0.082 \mathrm{mg} \mathrm{L}^{-1} \mathrm{NH}_{3}-\mathrm{N}$ (Table 3). 
Table 3 Tolerance of larval cod to ammonia for each observation period

\begin{tabular}{|c|c|c|c|c|c|c|c|c|}
\hline & & \multicolumn{7}{|c|}{ Ammonia concentration $\left(\mathrm{mg} \mathrm{L}^{-1} \mathrm{NH}_{3}-\mathrm{N}\right)$} \\
\hline & & & $0-24 \mathrm{~h}$ & & $24-48 \mathrm{~h}$ & & $0-48 \mathrm{~h}$ & \\
\hline $\begin{array}{l}\text { Age } \\
\qquad(\mathrm{dph})\end{array}$ & $\begin{array}{l}\text { Larval size } \\
\quad(\mathrm{mg} \mathrm{DW})\end{array}$ & $\begin{array}{l}\text { Upper } \\
\text { conc. used }\end{array}$ & NOEC & LOEC & NOEC & LOEC & NOEC & LOEC \\
\hline 15 & 0.211 & 0.012 & 0.012 & n.e. & 0.012 & n.e. & 0.012 & n.e. \\
\hline 20 & 0.414 & 0.046 & 0.046 & n.e. & 0.046 & n.e. & 0.046 & n.e. \\
\hline 24 & 0.569 & 0.082 & 0.045 & 0.082 & 0.045 & 0.082 & 0.045 & 0.082 \\
\hline 33 & 1.015 & 0.093 & 0.013 & 0.019 & 0.013 & 0.019 & 0.013 & 0.019 \\
\hline 42 & 1.678 & 0.027 & 0.013 & 0.027 & 0.027 & n.e. & 0.013 & 0.027 \\
\hline 58 & 4.341 & 0.031 & 0.031 & n.e. & 0.031 & n.e. & 0.031 & n.e. \\
\hline 63 & 4.938 & 0.085 & 0.026 & 0.045 & 0.026 & 0.045 & 0.026 & 0.045 \\
\hline
\end{tabular}

Actual tolerance is found somewhere in the interval between the highest concentration where no effect on mortality was observed (NOEC) and the lowest concentration where a significant effect was observed (LOEC), as determined from one-way ANOVA with Dunnett's or Games and Howell post hoc tests. Failure of detecting LOEC is marked with n.e. (not encountered)

\section{Discussion}

There is less information on ammonia toxicity in marine teleosts compared with freshwater species and fewer chronic studies versus acute. The mean acute TAN toxicity reviewed for marine teleosts $\left(\mathrm{LC}_{50}\right.$ of $\left.1.86 \mathrm{mg} \mathrm{L}^{-1}\right)$ suggests a higher sensitivity than in freshwater species $\left(2.79 \mathrm{mg} \mathrm{L}^{-1}\right)$, perhaps due to the higher $\mathrm{NH}_{4}{ }^{+}$permeability (Ip et al. 2001; Randall and Tsui 2002). For the early life stages, there are to our knowledge no published ammonia toxicity studies on Atlantic cod. However, for juveniles of this species, chronic ammonia exposure affected growth negatively at $0.06-0.12 \mathrm{mg} \mathrm{L}^{-1}$ $\mathrm{NH}_{3}-\mathrm{N}$ (Foss et al. 2004; Remen et al. 2008). In another study on young Atlantic cod juveniles, chronic exposure showed negative effects at ammonia levels as low as $0.0018 \mathrm{mg} \mathrm{L}^{-1} \mathrm{NH}_{3}-\mathrm{N}$, although this study was designed for investigating the combined impacts of several water quality parameters and not the effect of ammonia alone (van der Meeren et al. 2011).

In four of the experiments, we succeeded in establishing tolerance intervals for acute ammonia exposure, while in the three remaining experiments, LOEC was not encountered. Thus, no concentration interval for ammonia tolerance could be given for cod larvae aged 15 , 20, and $58 \mathrm{dph}$. In the exposures that LOEC was encountered, NOEC was found between 0.013 and $0.045 \mathrm{mg} \mathrm{L}^{-1} \mathrm{NH}_{3}-\mathrm{N}$, while LOEC was in the range of 0.019 to $0.082 \mathrm{mg} \mathrm{L}^{-1} \mathrm{NH}_{3^{-}}$ $\mathrm{N}$. Among the scarce marine larval fish data on acute ammonia toxicity (Table 4), different effect measures (ranging from NOEC to $\mathrm{LC}_{50}$ ), endpoint parameters (e.g. mortality, feeding behaviour or tissue damages), environmental conditions (a range of salinities, $\mathrm{pH}$, or temperatures), or time period of exposure (12-96 h), make it difficult to compare results. Nevertheless, the observed LOEC of Atlantic cod larvae are well within the ranges of $\mathrm{LC}_{10}$ and LOEC affecting mortality found in several other marine fish larvae (Table 4). Since stressors in larviculture of marine fish should be avoided as much as possible, the recommended maximum $\mathrm{NH}_{3}-\mathrm{N}$ concentration for acute exposure should not exceed LOEC. Thus, the present results suggest a level below $0.013 \mathrm{mg} \mathrm{L}^{-1} \mathrm{NH}_{3}-\mathrm{N}$ for Atlantic cod larvae.

Furthermore, the data indicates an ontogenetic shift in acute ammonia tolerance since larval mortality at 33 and $42 \mathrm{dph}(1.0-1.7 \mathrm{mg}$ DW) was higher than for other developmental stages. It should be noted that mortality in the unexposed controls was also highest at this stage of development, suggesting that handling (i.e. catch of cod larvae in the rearing tank and transfer 


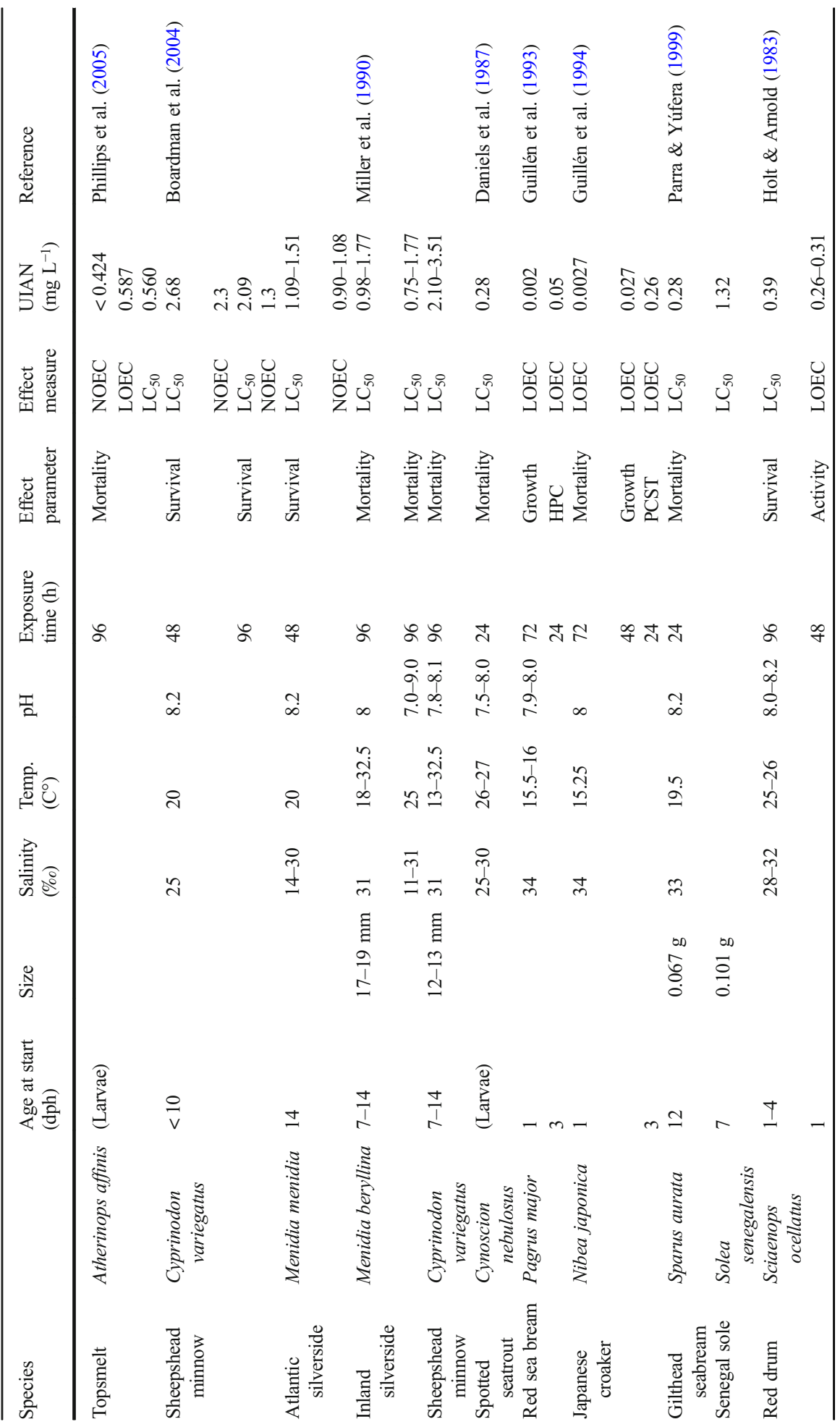




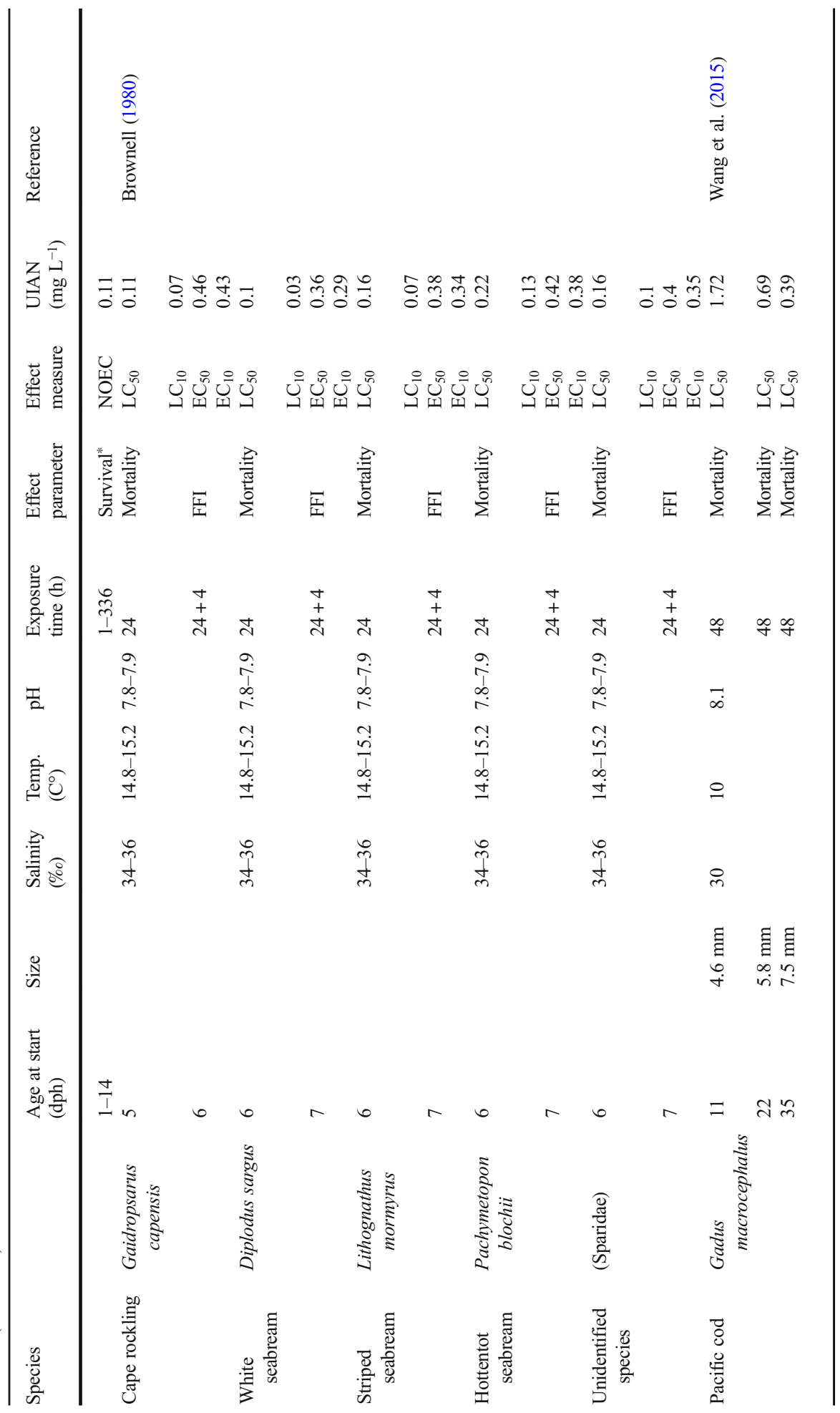




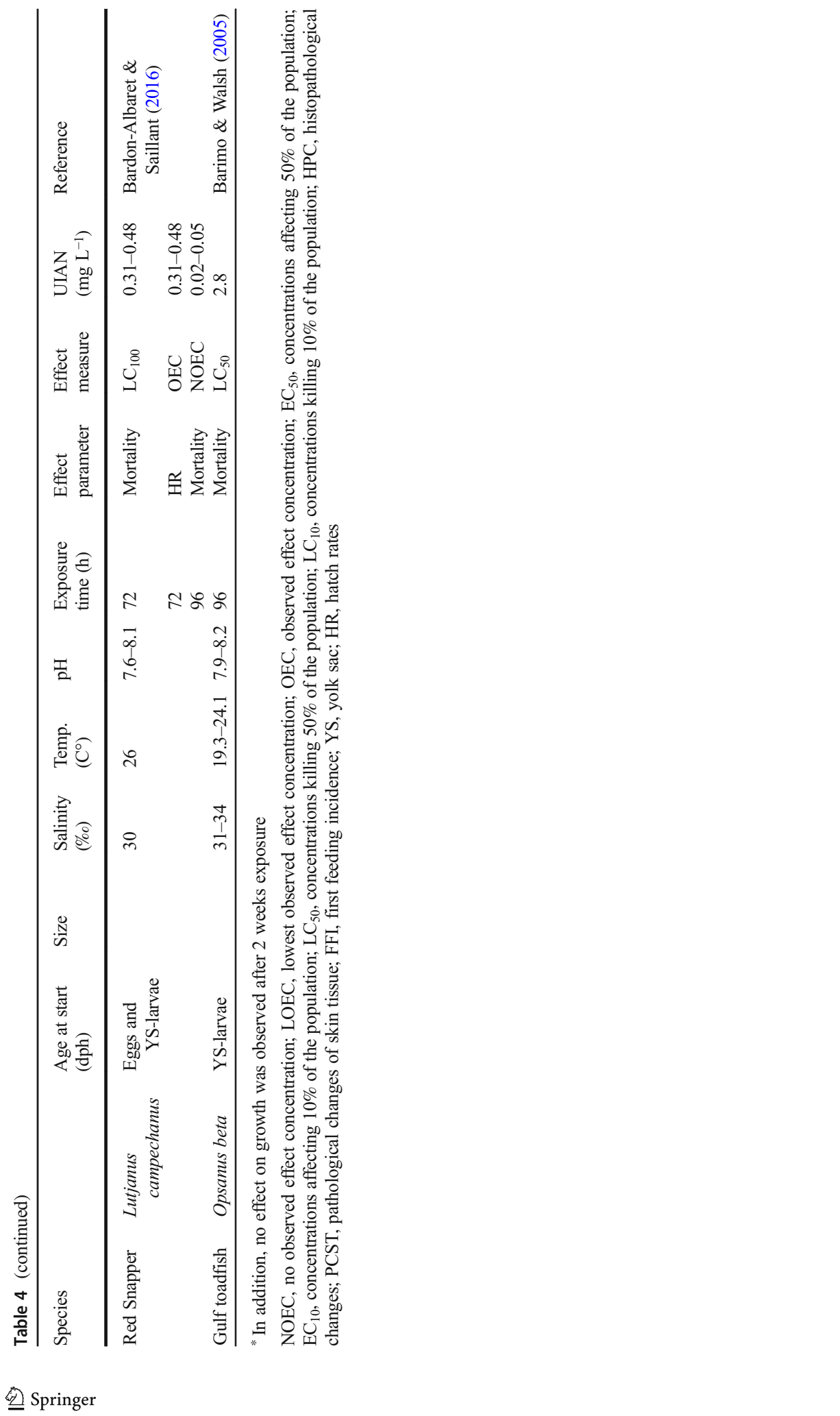


to the exposure tanks) may have affected larval survival. However, any effect of handling will most likely appear the first $24 \mathrm{~h}$, leaving mortality during the next $24 \mathrm{~h}$ to be assigned to ammonia exposure. The same change in sensitivity to ammonia with increasing age was also observed between 24 and $48 \mathrm{~h}$ of exposure. Decreasing ammonia tolerance with increasing larval age has been observed for the near-related species Pacific cod (Gadus macrocephalus) (Wang et al. 2015) but contrasts the findings for red drum (Sciaenops ocellatus) larvae where tolerance increased with larval age (Holt and Arnold 1983).

Most TAN studies in fish have been carried out on older juveniles or adults, which display large differences to larval fish regarding metabolism and sites of respiration and excretion (Zimmer et al. 2017). During the late egg stages, ammonium concentrations seem to accumulate in the marine fish embryo and decline rapidly after hatching indicating presence of mechanisms for detoxification or higher tolerance for ammonia during the egg stage. This may be explained by the longer diffusion distance in an encapsulated embryo compared with the hatched larvae. In juvenile fish, the ammonia is mainly excreted by diffusion from the gills or by active transport through exchange mechanisms also located in the gill epithelium (Wilkie 1997). These transport mechanisms are known to be situated in close conjunction to chloride cells. In the early larval stages, the gills are not functional, and the site for oxygen uptake is the body surface. Similarly, cutaneous ammonia excretion may take place in marine fish larvae, as suggested in a review of ammonia handling in early life stages of fish (Zimmer et al. 2017). Marine fish larvae have been demonstrated to have chloride cells scattered all over the body surface but mainly in the opercular area or yolk-sac membrane (Mangor-Jensen and Adoff 1987; Kaneko et al. 2002). In the present study, the increased sensitivity to ammonia during the period from 33 to 42 dph may be seen in connection with the transition from cutaneous ionic regulation to functional gills, as gill filaments with chloride cells and gill lamella appear at this age (Morrison 1993). Moreover, since the mass-specific metabolic rates are much higher in young larval cod compared with older stages, (Finn et al. 2002), this may imply elevated internal ammonia levels. This can also be seen in older fish when high metabolic rates are associated with feeding, swimming, or stress (Eddy 2005). Compared with slow-growing older fish, vulnerability to environmental TAN may therefore be higher in fast-growing larvae and early juveniles, but data on tolerance levels for these early developmental stages in marine fish are scarce. The observed increase in ammonia sensitivity also corresponds closely to larval sizes where a change from allometric to near-isometric growth occurs in Atlantic cod (Finn et al. 2002), indicating the start of substantial changes in body proportions. However, as routine metabolic rate in larval Atlantic cod scaled allometrically throughout the whole period of larval development with decreasing mass-specific rates, Finn et al. (2002) did not find any sudden change in the rate of ammonia excretion related to changes in larval size and body proportions.

Experiments on acute ammonia exposure for temperate and warm water marine fish larvae have shown effects during early development on initiation of first feeding, skin cells pathology, cytoplasmic vacuolisation of chondrocytes, growth rate, and larval survival at $\mathrm{NH}_{3}$ concentrations within the range of 0.0027-0.3 mg L L $^{-1}$ (Brownell 1980; Guillén et al. 1993, 1994; Parra and Yúfera 1999). The present study on Atlantic cod larvae found effects between 0.019 and $0.082 \mathrm{mg} \mathrm{L}^{-1}$ $\mathrm{NH}_{3}-\mathrm{N}$ which is well within this range. Since safe levels of ammonia vary between species, a direct comparison of data from other species to Atlantic cod is difficult at best. However, depending on hatchery system and management, fish larvae might be exposed to multiple stressors, e.g. nutrition, temperature, oxygen levels, $\mathrm{pH}, \mathrm{CO}_{2}$ levels from respiration, microbial activity, and ammonia (van der Meeren et al. 2011; Karlsen et al. 2015). The combined effect of such stressors may increase sensitivity to each of these factors, leading to developmental malformations or reduced survival at thresholds lower than expected from separate studies of the stressors. The impacts of combined 
stress effects may be strongest in the larval stages when developmental rate and mass-specific metabolism and growth are at the maximum during the life history of fishes. Safe limits of ammonia may therefore be specific to species and developmental stage, and setting safe limits also requires successful management in keeping other stressors at acceptable levels. Further, chronic ammonia exposure has not been investigated so far for Atlantic cod larvae. Chronic exposure may occur more readily towards the end of a larval production cycle with the accumulation of biomass, feed, and waste, regardless of the type of rearing system. Considering toxicity of chronic ammonia exposure in the range of 5-10\% of acute tolerance (Eddy 2005), effects of longtime exposure should be expected to appear at the range of $0.002-0.008 \mathrm{mg} \mathrm{L}^{-1} \mathrm{NH}_{3}-\mathrm{N}$.

The variations in ammonia toxicity found in the present study were not followed by histology or biochemical verifications of organ failure at tissue or cellular levels. Exposure to acute ammonia stress during development of the ammonia detox systems (Steele et al. 2001; Barimo et al. 2004) may result in differences in sensitivity. Such systems include both ionic regulation and enzymes to convert ammonia to the low toxic urea (Chadwick and Wright 1999; Terjesen et al. 2008; Cameron and Heisler 1983). Of the acute toxicity effects found in the present study, neurologic and osmoregulatory failure are the two most plausible causes of death. However, newer molecular methods may enable more detailed studies at the gene level of such mechanisms and other sub-lethal perturbations of ammonia stress.

Acknowledgements We thank the technical staff at IMR-Austevoll for excellent assistance in carrying out start feeding and providing live food for the cod larvae used in the exposure experiments.

Funding information Open access funding provided by Institute of Marine Research. The study was financed by The Norwegian Research Council, grant no. 141768/120.

\section{Compliance with ethical standards}

Conflict of interest The authors declare that they have no conflict of interest.

Ethical approval "All applicable national and institutional guidelines for the care and use of animals were followed by the authors. The experiment was in accordance with a permission given by the Norwegian FDU (FOTS ID 13907). All means to minimize larval mortality was carried out by carefully selecting ammonia exposure concentrations."

Open Access This article is licensed under a Creative Commons Attribution 4.0 International License, which permits use, sharing, adaptation, distribution and reproduction in any medium or format, as long as you give appropriate credit to the original author(s) and the source, provide a link to the Creative Commons licence, and indicate if changes were made. The images or other third party material in this article are included in the article's Creative Commons licence, unless indicated otherwise in a credit line to the material. If material is not included in the article's Creative Commons licence and your intended use is not permitted by statutory regulation or exceeds the permitted use, you will need to obtain permission directly from the copyright holder. To view a copy of this licence, visit http://creativecommons.org/licenses/by/4.0/.

\section{References}

Alabaster JS, Shurben DG, Knowles G (1979) The effect of dissolved oxygen and salinity on the toxicity of ammonia to smolts of salmon, Salmon salar L. J Fish Biol 15:705-712. https://doi.org/10.1111/j.10958649.1979.tb03680.x

Attramadal KJK, Salvesen I, Xue R, Øie G, Størseth TR, Vadstein O, Olsen Y (2012) Recirculation as a possible microbial control strategy in the production of marine larvae. Aquacultural Engineering 46, 27-39. https://doi.org/10.1016/j.aquaeng.2011.10.003 
Alam M, Frankel T (2006) Gill ATPase activities of silver perch, Bidyanus bidyanus (Mitchell), and golden perch, Macquaria ambigua (Richardson): effects of environmental salt and ammonia. Aquaculture 251:118133. https://doi.org/10.1016/j.aquaculture.2005.05.028

Bardon-Albaret A, Saillant EA (2016) Effects of hypoxia and elevated ammonia concentration on the viability of red snapper embryos and early larvae. Aquaculture 459:148-155. https://doi.org/10.1016/j. aquaculture.2016.03.042

Barimo JF, Steele SL, Wright PA, Walsh PJ (2004) Dogmas and controversies in the handling of nitrogenous wastes: ureotely and ammonia tolerance in early life stages of the gulf toadfish, Opsanus beta. J Exp Biol 207:2011-2020. https://doi.org/10.1242/jeb.00956

Barimo JF, Walsh PJ (2005) The effects of acute and chronic ammonia exposure during early life stages of the gulf toadfish, Opsanus beta. Aquat Toxicol 75:225-237. https://doi.org/10.1016/j. aquatox.2005.08.005

Boardman GD, Starbuck SM, Hudgins DB, Li X, Kuhn DD (2004) Toxicity of ammonia to three marine fish and three marine invertebrates. Environ Toxicol 19:134-142. https://doi.org/10.1002 /tox.20006

Bower CE, Holm-Hansen T (1980) A salicylate-hypochlorite method for determining ammonia in seawater. Can J Fish Aquat Sci 37:794-798. https://doi.org/10.1139/180-106

Brownell C (1980) Water quality requirements for first-feeding in marine fish larvae. I. Ammonia, nitrite, and nitrate. J Exp Mar Biol Ecol 44:269-283. https://doi.org/10.1016/0022-0981(80)90158-6

Cameron JN, Heisler N (1983) Studies of ammonia in the rainbow trout: physico-chemical parameters, acid-base behaviour and respiratory clearance. J Exp Biol 105:107-125

Chadwick TD, Wright PA (1999) Nitrogen excretion and expression of urea cycle enzymes in the Atlantic cod (Gadus morhua L.): a comparison of early life stages with adults. J Exp Biol 202: 2653-2662

Cheng C-H, Yang F-F, Ling R-Z, Liao S-A, Miao Y-T, Ye C-X, Wang A-L (2015) Effects of ammonia exposure on apoptosis, oxidative stress and immune response in pufferfish (Takifugu obscurus). Aquat Toxicol 164: 61-71. https://doi.org/10.1016/j.aquatox.2015.04.004

Crane M, Newman MC (2000) What level of effect is a no observed effect? Environ. Toxicol Chem 19:516-519. https://doi.org/10.1002/etc.5620190234

Eddy FB (2005) Ammonia in estuaries and effects on fish. J Fish Biol 67:1495-1513. https://doi.org/10.1111 /j.1095-8649.2005.00930.x

Daniels HV, Boyd CE, Vernon Minton R (1987) Acute toxicity of ammonia and nitrite to spotted sea trout. Prog Fish-Cult 49:260-263. https://doi.org/10.1577/1548-8640(1987)49<260:ATOAAN>2.0. $\mathrm{CO} ; 2$

Felipo V, Butterworth R (2002) Neurobiology of ammonia. Prog Neurobiol 67:259-279. https://doi.org/10.1016 /S0301-0082(02)00019-9

Finn RN, Rønnestad I, van der Meeren T, Fyhn HJ (2002) Fuel and metabolic scaling during the early life stages of Atlantic cod Gadus morhua. Mar Ecol Prog Ser 243:217-234. https://doi. org/10.3354/meps 243217

Fivelstad S (1988) Waterflow requirements for salmonids in single-pass and semi-closed land-based seawater and freshwater systems. Aquac Eng 7:183-200. https://doi.org/10.1016/0144-8609(88 )90020-9

Foss A, Siikavuopio SI, Sæther B-S, Evensen TH (2004) Effect of chronic ammonia exposure on growth in juvenile Atlantic cod. Aquaculture 237:179-189. https://doi.org/10.1016/j. aquaculture.2004.03.013

Guillén JL, Endo M, Turnbull JF, Kawatsu H, Richards RH, Aoki T (1993) Depressed growth rate and damage to the cartilage of red sea bream larvae associated with exposure to ammonia. Nippon Suisan Gakkaishi 59: 1231-1234. https://doi.org/10.2331/suisan.59.1231

Guillén JL, Endo M, Turnbull JF, Kawatsu H, Richards RH, Aoki T (1994) Skin responses and mortalities in the larvae of Japanese croaker exposed to ammonia. Fish Sci 60:547-550

Handy RD, Poxton MG (1993) Nitrogen pollution in mariculture: toxicity and excretion of nitrogenous compounds by marine fish. Rev Fish Biol Fish 3:205-241. https://doi.org/10.1007/BF00043929

Holt GJ, Arnold CR (1983) Effects of ammonia and nitrite on growth and survival of red drum eggs and larvae. Trans Am Fish Soc 112:314-318. https://doi.org/10.1577/1548-8659(1983)112<314 :EOAANO $>2.0 . \mathrm{CO} ; 2$

Ip YK, Chew SF, Randall DJ (2001) Ammonia toxicity, tolerance, and excretion. In: Wright PA, Anderson PM (eds) Fish physiology. Academic Press, New York, pp 109-148

Kaneko T, Shiraishi K, Katoh H, Hasegawa S, Hiroi J (2002) Chloride cells during early life stages of fish and their functional differentiation. Fish Sci 68:1-9. https://doi.org/10.1046/j.14442906.2002.00382.x 
Karlsen Ø, van der Meeren T, Rønnestad I, Mangor-Jensen A, Galloway TF, Kjørsvik E, Hamre K (2015) Copepods enhance nutritional status, growth and development in Atlantic cod (Gadus morhua L.) larvae - can we identify the underlying factors? PeerJ 3:e902. https://doi.org/10.7717/peerj.902

Mangor-Jensen A, Adoff G (1987) Drinking activity of the newly hatched larvae of cod Gadus morhua L. Fish Physiol Biochem 3:99-103. https://doi.org/10.1007/BF02183004

Miller DC, Poucher S, Cardin JA, Hansen D (1990) The acute and chronic toxicity of ammonia to marine fish and a mysid. Arch Environ Contam Toxicol 19:40-48. https://doi.org/10.1007 /BF01059811

Morrison M (1993) Histology of the Atlantic cod, Gadus morhua: an atlas. Part 4. Eleutheroembryo and larva. Can Spec Publ Fish Aquat Sci 119496 p

Nijhof M, Bovendeur J (1990) Fixed film nitrification characteristics in sea-water recirculation fish culture systems. Aquaculture 87:133-143. https://doi.org/10.1016/0044-8486(90)90270-W

Noble A, Summerfeldt S (1996) Diseases encountered in rainbow trout cultured in recirculating systems. Annu Rev Fish Dis 6:65-92. https://doi.org/10.1016/S0959-8030(96)90006-X

Parra G, Yúfera M (1999) Tolerance response to ammonia and nitrite exposure in larvae of two marine fish species (gilthead seabream Sparus aurata L. and Senegal sole Solea senegalensis Kaup). Aquac Res 30: 857-863. https://doi.org/10.1046/j.1365-2109.1999.00414.x

Phillips BM, Nicely PA, Hunt JW, Anderson BS, Tjeerdema RS, Palmer FH (2005) Tolerance of five west coast marine toxicity test organisms to ammonia. Bull Environ Contam Toxicol 75:23-27. https://doi.org/10.1007 /s00128-005-0713-0

Pierce RH, Weeks JM, Prappas JM (1993) Nitrate toxicity to five species of marine fish. J World Aquacult Soc 24:105-107. https://doi.org/10.1111/j.1749-7345.1993.tb00156.x

Randall DJ, Tsui TKN (2002) Ammonia toxicity in fish. Mar Pollut Bull 45:17-23. https://doi.org/10.1016 /S0025-326X(02)00227-8

Remen M, Imsland AK, Stefansson SO, Jonassen TM, Foss A (2008) Interactive effects of ammonia and oxygen on growth and physiological status of juvenile Atlantic cod (Gadus morhua). Aquaculture 274:292-299. https://doi.org/10.1016/j.aquaculture.2007.11.032

Rodrigues RV, Romano LA, Schwarz MH, Delbos B, Sampaio LA (2014) Acute tolerance and histopathological effects of ammonia on juvenile maroon clownfish Premnas biaculeatus (block 1790). Aquac Res 45:11331139. https://doi.org/10.1111/are.12054

Shanahan JW, Semmens MJ (2015) Alkalinity and pH effects on nitrification in a membrane aerated bioreactor: an experimental and model analysis. Water Res 74:10-22. https://doi.org/10.1016/j. watres.2014.12.055

Soderberg RW, Meade JW (1991) The effects of ionic strength on un-ionized ammonia concentration. Prog Fish-Cult 53:118-120. https://doi.org/10.1577/1548-8640(1991)053\%3C0118:TEOISO\%3 E2.3.CO;2

Sokal RR, Rohlf FJ (1995) Biometry, third edn. WH Freeman and Company, New York

Steele SL, Chadwick TD, Wright PA (2001) Ammonia detoxification and localization of urea cycle enzyme activity in embryos of the rainbow trout (Oncorhynchus mykiss) in relation to early tolerance to high environmental ammonia levels. J Exp Biol 204:2145-2154

Terjesen BF (2008) Nitrogen excretion. In: Finn RN, Kapoor BG (eds) Fish larval physiology. Science Publisher, Enfield, pp 263-302

van der Meeren T, Ivannikov VP (2006) Seasonal shift in spawning of Atlantic cod (Gadus morhua L.) by photoperiod manipulation: egg quality in relation to temperature and intensive larval rearing. Aquac Res 37 : 898-913. https://doi.org/10.1111/j.1365-2109.2006.01510.x

van der Meeren T, Mangor-Jensen A, Pickova J (2007) The effect of green water and light intensity on survival, growth and lipid composition in Atlantic cod (Gadus morhua) during intensive larval rearing. Aquaculture 265:206-217. https://doi.org/10.1016/j.aquaculture.2007.01.042

van der Meeren T, Brunvold L, Sandaa R-E, Bergh Ø, Castberg T, Thyrhaug R, Mangor-Jensen A (2011) Water quality and microbial community structure in juvenile Atlantic cod (Gadus morhua L.) cultures. Aquaculture 316:111-120. https://doi.org/10.1016/j.aquaculture.2011.03.016

Wang W, Wang H, Yu C, Jiang Z (2015) Acute toxicity of ammonia and nitrite to different ages of Pacific cod (Gadus macrocephalus) larvae. Chem Speciat Bioavailab 27:147-155. https://doi.org/10.1080 /09542299.2015.1113389

Weihrauch D, Wilkie MP, Walsh JP (2009) Ammonia and urea transporters in gills of fish and aquatic crustaceans. J Exp Biol 212:1716-1730. https://doi.org/10.1242/jeb.024851

Whitfield M (1974) The hydrolysis of ammonium ions in sea water - a theoretical study. J Mar Biol Assoc UK 54:565-580. https://doi.org/10.1017/S002531540002275X

Wilkie MP (1997) Mechanisms of ammonia excretion across fish gills. Comp Biochem Physiol 118A:39-50. https://doi.org/10.1016/S0300-9629(96)00407-0 
Wilkie MP (2002) Ammonia excretion and urea handling by fish gills: present understanding and future research challenges. J Exp Zool 293:284-301. https://doi.org/10.1002/jez.10123

Wright PA, Fyhn HJ (2001) Ontogeny of nitrogen metabolism and excretion. In: Wright PA, Anderson PM (eds) Fish physiology. Academic Press, London, New York, pp 149-200

Wright PA, Wood CM (2012) Seven things fish know about ammonia and we don't. Respir Physiol Neurobiol 184:231-240. https://doi.org/10.1016/j.resp.2012.07.003

Zimmer AM, Wright PA, Wood CM (2017) Ammonia and urea handling by early life stages of fishes. J Exp Biol 220:3843-3855. https://doi.org/10.1242/jeb.140210

Publisher's note Springer Nature remains neutral with regard to jurisdictional claims in published maps and institutional affiliations. 